\title{
Literasi Zakat Hasil Perkebunan Kelapa Sawit
}

\author{
Nora Septini Harahap', Zulaika Matondang², Delima Sari Lubis ${ }^{3}$ \\ 1,2,Institut Agama Islam Negeri Padangsidimpuan
}

JL. H.T. Rizal Nurdin Km 4,5 Sihitang Kota Padangsidimpuan_Sumatera Utara ola.seftiny@gmail.com¹, zulaikamatondang@iain-padangsidimpuan.ac.id², delimasari@iain-padangsidimpuan.ac.id ${ }^{3}$

\begin{abstract}
South Labuhanbatu Regency is one of the largest fresh fruit bunch producing areas in Indonesia with the majority of the population being Muslim, so South Labuhanbatu Regency should have a large zakat potential for oil palm plantations in South Labuhanbatu Regency. Apparently, not in line with the expectations that occur in the field with the low level of literacy among oil palm farmers, causing delays in the distribution of zakat funds that should be paid annually, this makes zakat on plantation products or commonly referred to as zakat on assets still taboo among the people of Labuhanbatu district. South especially oil palm farmers. This should be a concern for everyone considering that zakat is not only a pillar of Islam that must be implemented, but zakat is also one of the most effective poverty alleviation instruments by developing productive zakat for the poor and needy. The zakat institution, BASNAZ, in South Labuhanbatu Regency, should take a look at this and take concrete actions in increasing zakat literacy for oil palm plantations in South Labuhanbatu Regency.
\end{abstract}

Keywords: Literacy, Zakat, BAZNAS

\begin{abstract}
ABSTRAK
Kabupaten Labuhanbatu Selatan merupakan salah satu daerah penghasil tandan buah segar terbesar di Indonesia dengan mayoritas penduduk beragama muslim, dengan begitu seharusnya kabupaten Labuhanbatu Selatan memiliki Potensi zakat perkebunan kelapa sawit yang besar di kabupaten Labuhanbatu Selatan. Ternyata, tidak sejalan dengan ekspetasi yang terjadi di lapangan dengan rendahnya tingkat literasi di kalangan para petani kelapa sawit menjadikan tersendatnya penyaluran dana zakat yang seharusnya ditunaikan setiap tahunnya, hal tersebut menjadikan zakat hasil perkebunan atau biasa disebut dengan zakat harta masih tabu di kalangan masyarakat kabupaten Labuhanbatu Selatan terutama para petani kelapa sawit. Sudah seharusnya hal ini menjadi perhatian setiap kalangan mengingat bahsanya zakat tidak hanya merupakan rukun islam yang wajib dilaksanakan namun, zakat juga merupakan slah satu instrument pengentas kemiskinan yang paling ampuh dengan mengembangkan zakat produktif pada kalangan fakir dan miskin. Sudah seharusnya lembaga zakat BASNAZ kabupaten Labuhanbatu Selatan melirik hal tersebut dan melakukan aksi nyata dalam meningkatkan literasi zakat perkebunan kelapa sawit di Kabupaten Labuhanbatu Selatan.
\end{abstract}

Kata Kunci: Literasi, Zakat, BAZNAS 


\section{PENDAHULUAN}

Secara umum zakat adalah suatu kewajiban yang wajib dikeluarkan dan bersifat kemasyarakatan serta ibadah bagi umat muslim, dimana manusia akan merasakan keagungan dari tujuan ajaran Islam dalam bentuk mencintai dan tolong menolong antar sesama manusia (Rouf, 2011). Zakat juga termasuk ibadah sosial dan merupakan salah satu ketetapan Allah yang menyangkut masalah harta yang dimiliki dan zakat merupakan rukun Islam yang ketiga. Oleh sebab itu zakat merupakan suatu sistem dalam masyarakat Islam untuk mengatasi masalah kemiskinan dan kesejahteraan masyarakat (Marinda, 2016). Disisi lain, diketahui bahwa zakat memiliki peranan yang besar dalam kehidupan manusia, salah satunya yaitu dalam bermasyarakat dikarenakan zakat merupakan manifestasi dari kegotong-royongan antara para hartawan dan fakir miskin (ash-Shiddieqy, 2009).

Rendahnya pengetahuan masyarakat terhadap penyaluran dana zakat menjadikan literasi zakat merupakan faktor yang sangat penting dalam menentukan keputusan muzakki dalam mengeluarkan zakatnya, hal tersebut dapat dilihat dari jumlah penduduk Indonesia dengan jumlah penduduk muslim terbesar di dunia dengan persentase penduduk muslimnya mencapai 85,2 persen dari total jumlah penduduk sebanyak 270.054.853 juta jiwa. Perhatian dan kesadaran masyarakat Indonesia dalam menunaikan zakat masih sangatlah rendah. Adapun besar potensi zakat pada tahun 2017 yaitu sebesar Rp 462 Triliun. Nilai potensi ini lebih tinggi jika dibandingkan dengan potensi zakat saat ini dimana regulasi yang berlaku adalah zakat sebagai pengurang penghasilan kena pajak, besarnya potensi tersebut masih belum sejalan dengan kenyataanya dilapangan. kenyataanya penghimpunan zakat nasional masih belum berjalan dengan optimal pada tahun 2017. Persoalan utama yang menyebabkan rendahnya realisasi penghimpunan zakat nasional yaitu akibat keterbatasan pemahaman umat Islam tentang arti dari esensi zakat, kesadaran dan pemahaman mengenai zakat (Ezhar, 2019).

Zakat maal merupakan bagian dari harta kekayaan seseorang juga badan hukum yang wajib dikeluarkan untuk golongan tertentu, setelah dimiliki dalam jangka waktu tertentu dan jumlah minimal tertentu. Dalam Undang Undang Nomor 23 Tahun 2011 tentang Pengelolaan Zakat pasal 4 ayat 2 menyebutkan bahwa harta yang dikenai zakat maal berupa emas, perak, uang, hasil pertanian dan perusahaan, hasil pertambangan, hasil peternakan, hasil pendapatan dan jasa, serta rikaz (Antariksa, 2015). Apabila Seseorang telah mencapai haulnya maka yang bersangkutan wajib mengeluarkan zakat, 
baik itu pegawai ataupun seseorang yang memiliki penghasilan setara dengan hasil panen yaitu $2.750 \mathrm{~kg}$ makanan pokok setiap panen (periode penerimaan penghasilan) sesuai dengan harga perkg beras didaerah setempat dan apabila telah mencapai haulnya maka wajib mengeluarkan zakat (Nur, 2018). Dalam hal tersebut hasil pertanian menjadi salah satu zakat maal (harta) yang memiliki prospektif yang besar, bisa dilihat dari hasil tani tingkat nasional yang ada di Indonesia, hasil pertanian kelapa sawit menjadi komoditas yang mendapatkan peringkat tertinggi dalam produksi hasil taninya, dapat dilihat dari data produksi pertanian pada tabel berikut.

Tabel 1. Presentase hasil komoditas pertanian di Indonesia

\begin{tabular}{|c|c|c|c|c|c|}
\hline NO & Jenis tanaman & 2015 & 2016 & 2017 & 2018 \\
\hline 1 & Karet & $0,56 \%$ & $0,60 \%$ & $0,59 \%$ & $0,58 \%$ \\
\hline \multirow[t]{4}{*}{2} & Sawit & & & & \\
\hline & Tandan sawit/ TBS & $68,46 \%$ & $74,39 \%$ & $74,80 \%$ & $72,65 \%$ \\
\hline & Minyak sawit & $18,00 \%$ & $16,70 \%$ & $17,82 \%$ & $18.06 \%$ \\
\hline & Inti sawit & $3,32 \%$ & $3,11 \%$ & $2,93 \%$ & $3,13 \%$ \\
\hline 3 & Coklat & - & - & - & - \\
\hline 4 & Teh & $0,64 \%$ & $0,74 \%$ & $0,59 \%$ & $0,51 \%$ \\
\hline 5 & Tembakau & $0,00 \%$ & $0,00 \%$ & $0,00 \%$ & $0,00 \%$ \\
\hline 6 & Kopi & - & - & o & o \\
\hline 7 & Tebu & $7,95 \%$ & $3,93 \%$ & $2,98 \%$ & $4,57 \%$ \\
\hline
\end{tabular}
http://jurnal.iain-padangsidimpuan.ac.id/index.php/JISFIM 


\begin{tabular}{|c|l|c|c|c|c|}
\hline 8 & Gula & $0,62 \%$ & $0,28 \%$ & $0,15 \%$ & $0,25 \%$ \\
\hline 9 & Tetes & $0,45 \%$ & $0,24 \%$ & $0,14 \%$ & $0,24 \%$ \\
\hline
\end{tabular}

Berdasarkan tabel 1 diatas menggambarkan bahwa hasil pertanian kelapa sawit merupakan komoditas yang paling tinggi dari semua komoditas hasil pertanian lainnya yang berada pada tingkat nasional, dan angka produksinya pun meningkat dari tahun ke tahun, hingga pada tahun 2018 telah mencapai 72,65 persen tandan sawit / TBS yang senilai dengan US\$ 440 per tonnya atau senilai 6.776.000 (ton), hal tersebut menandakan nilai sumbangan devisa minyak kelapa sawit Indonesia sepanjang 2018 dapat mencapai US\$20,54 miliar atau setara dengan Rp289 Triliun ((BPS), 2020).

Besarnya hasil dari pertanian kelapa sawit tersebut menjadikan kelapa sawit menjadi komoditas hasil pertanian yang memiliki prospek potensi zakat yang sangat potensial. Dalam hal tersebut Kabupaten Labuhanbatu Selatan merupakan salah satu daerah di Provinsi Sumatera Utara yang memiliki lahan kelapa sawit yang tidak terlalu luas namun produksi kelapa sawitnya tinggi. Labuhanbatu Selatan merupakan salah satu dari lima kabupaten dengan penghasil tandan buah segar dengan produksi tandan buah segar tertinggi. Satu hektar lahan kelapa sawit produktif yang berada di Kabupaten Labuhanbatu Selatan dapat menghasilkan 500 sampai 600 kilogram TBS dalam sekali panen dan dalam sebulan dapat dilakukan dua sampai tiga kali panen dan dapat menghasilkan maksimal 400 kilogram dalam sekali panen (Agustin, 2018). Hasil dari produksi perkebunan kelapa sawit per-kecamatan di Kabupaten Labuhanbatu Selatan (Ribu ton) dalam tahun 2017-2019 dapat kita lihat pada tabel berikut. 
Tabel 2. Hasil produksi kelapa sawit dari tahun 2017-2019 per-kecamatan di Kabupaten Labuhanbatu Selatan.

\begin{tabular}{|c|l|c|c|c|c|c|c|}
\hline \multirow{2}{*}{ NO } & \multirow{2}{*}{ Kecamatan } & \multicolumn{2}{|c|}{ Tahun (Ribu TON) } & \multicolumn{2}{c|}{ Tahun (\%) } \\
\cline { 3 - 8 } & & $\mathbf{2 0 1 7}$ & $\mathbf{2 0 1 8}$ & $\mathbf{2 0 1 9}$ & $\mathbf{2 0 1 7}$ & $\mathbf{2 0 1 8}$ & $\mathbf{2 0 1 9}$ \\
\hline 1 & $\begin{array}{l}\text { Sungai } \\
\text { Kanan }\end{array}$ & 156,08 & 156,08 & 158,42 & $23 \%$ & $23 \%$ & $25 \%$ \\
\hline 2 & Torgamba & 132,92 & 132,92 & 110,21 & $20 \%$ & $20 \%$ & $17 \%$ \\
\hline 4 & Kota Pinang & 153,77 & 153,77 & 142,91 & $23 \%$ & $23 \%$ & $22 \%$ \\
\hline 5 & $\begin{array}{l}\text { Kilangkitang } \\
\text { Kakyat }\end{array}$ & 47,18 & 47,18 & 58,86 & $7 \%$ & $7 \%$ & $9 \%$ \\
\hline \multirow{2}{*}{ TOTAL } & & 177,19 & 177,19 & 169,79 & $27 \%$ & $27 \%$ & $27 \%$ \\
\hline
\end{tabular}

Sumber : www.bps.go.id

Dari tabel tersebut dapat diketahui bahwa setiap kecamatan yang berada di kabupaten Labuhanbatu Selatan memiliki hasil produksi kelapa sawit yang cenderung stabil setiap tahunnya. Hasil prodiksi tertinggi terdapat pada tahun 2017 dan 2018 yang menghasilkan 667,14 Ribu ton atau setara dengan RP.45 Miliyar pada tahun 2017 dan 2018. Sedaangkan pada tahun 2019 mengalami penurunan, namun tidak begitu singnifikan sehingga pada tahun 2019 hasil produksi kelapa sawit senilai Rp.43 Miliyar, angka tersebut merupakan angka yang cukup besar apabila hasil dari produksi pertanian kelapa sawit tersebut dibayarkan zakatnya. 


\section{METODE PENELITIAN}

Penelitian ini menggunakan metode pendekatan kualitatif, karena penelitian ini mengkonfirmasi konsep dan teori yang telah dijelaskan pada bab sebelumnya dengan fakta dan data yang ditemukan di lapangan, jenis penelitian ini adalah penelitian lapangan atau pada responden dan penelitian yang digunakan penulis adalah metode pendekatan kualitatif, Penelitian kualitatif adalah jenis penelitian yang temuantemuannya tidak diperoleh melalui prosedur statistik atau bentuk hitungan lainnya (Corbin, 2003). Penelitian kualitatif adalah suatu proses penelitian dan pemahaman yang berdasarkan pada metodologi yang menyelidiki suatu fenomena sosial dan masalah manusia (Noor, 2013). Menurut Nurul Zuhriahyang menghasilkan data deskriptif berupa kata-kata tertulis dari orang-orang atau pelaku yang dapat diamati (Zuhriah, 2006). Metode kualitatif adalah sebagai prosedur penelitian yang menghasilkan data deskriptif berupa kata-kata tertulis atau lisan dari orang-orang dan perilaku yang diamati, sedangkan menurut Lexy J. Moleong Penelitian kualitatif adalah tradisi tertentu dalam ilmu pengetahuan sosial secara fundamental (fakta dan nyata) bergantung pada pengamatan pada manusia dalam kawasannya sendiri berhubungan dengan orang-orang tersebut dalam bahasanya dan dalam peristilahannya (Moleong, 2012).

Subjek penelitian adalah sesuatu yang diteliti baik orang, benda, ataupun lembaga (organisasi) Jika kita bicara tentang subjek penelitian, sebetulnya kita berbicara tentang unit analisis, yaitu objek yang menjadi pusat perhatian atau sasaran peneliti (Rachmat, 2010). Oleh kerna itu dalam penelitian ini yang menjadi objeknya literasi zakat perkebunan petani kelapa sawit di Kabupaten Labuhanbatu Selatan adalah para petani kelapa sawit di Kabupaten Labuhanbatu Selatan.

\section{Sumber Data}

Sumber data penelitian ini terdiri dari dua sumber yaitu data primer dan sekunder yakni; Data primer, data Primer adalah data yang diperoleh secara langsung dari subjek penelitian sebagai informasi. Data primer dalam penelitian ini diperoleh dengan cara di survay secara langsung atau melakukan wawancara kepada yang bersangkutan; Data sekunder, data Sekunder adalah data yang diperoleh secara tidak langsung dari subjek penelitian sebagai informasi. Untuk penelitian ini data sekunder diperoleh dari dokumen, laporan-laporan, buku, jurnal penelitian, dan artikel yang masih berkaitan 
dengan materi yang sedang peneliti lakukan (Vijaya, Metodologi penelitian bisnis., 2014).

\section{Teknik Pengumpulan Data}

Teknik pengumpulan data merupakan langkah yang paling utama dalam penelitian, karena tujuan utamanya ialah mendapatkan data. Untuk memperkuat data yang diperoleh maka perlu adanya proses pengumpulan data meliputi: (1)Observasi merupakan pengamatan langsung kepada objek penelitian dengan cara mencatat data, mengadakan pertimbangan, kemudian mengadakan penilaian kedalam suatu skala bertingkat. (2)Wawancara Mendalam (Indepth Interviews) Wawancara adalah metode atau cara mengumpulkan data serta berbagai informasi dengan jalan menanyakan langsung kepada seseorang yang dianggap ahli dalam bidangnya dan juga yang berwenang dalam menyelesaikan suatu permasalahan. (3)Focus Grup Discussions (FGDs). Dalam teknik wawancara ini, peneliti mengumpulkan beberapa informan kunci untuk mendiskusikan masalah penelitian. Bentik wawancara ini dapat berupa semi terstruktur (semi- structured intirviews) dan wawancara mendalam (in-depth interviews). (4)Dokumentasi. Dokumentasi yaitu rekaman kejadian masalah lalu yang ditulis atau dicetak dapat berupa catatan, transkip, buku, surat kabar, majalah, prasasti, agenda, dan sebagainya. Pakar lain menjelaskan teknik pengembalian data yang diperoleh melalui dokumen-dokumen (bandur, 2016). Pengumpulan data melalui studi dokumen pada penelitian ini dilakukan untuk melengkapi data yang diperoleh dari kegiatan observasi dan wawancara. Oleh karena itu, studi dokumen dalam penelitian ini dilakukan dengan mengkaji dan mempelajari seluruh dokumen yang ada kaitannya dengan analisis faktor yang mempengaruhi minat masyarakat dalam mengeluarkan zakat pertanian pada petani kelapa sawit di kabupaten labuhan batu selatan.

\section{Teknik Pengelolaan dan Analisis Data}

Teknik Pengelolaan Data pada Penelitian ini dilakukan dalam bentuk deskriptif kualitatif yaitu penelitian yang berusaha menggambarkan dan menginterpresentasikan objek sesuai dengan apa adanya dan sering disebut dengan penelitian non eksperimen. Maka proses atau teknik pengolahan data yang digunakan adalah analisis data kualitatif dalam bentuk deskriptif. Karena pada penelitian ini, peneliti tidak melakukan manipulasi data penelitian dan tujuan utama penelitian ini adalah menggambarkan secara sistematik fakta dan karakteristik objek atau subjek yang diteliti secara tetap (Sukardi, Metodologi Penelitian Kompetensi dan Prakteknya, 2003). 


\section{Analisis Data}

Analisis data adalah proses mencari dan menyusun secara sistematis data yang diperoleh dari hasil wawancara, catatan lapangan, dan bahan-bahan lain, sehingga dapat mudah dipahami, dan temuannya dapat diinformasikan kepada orang lain (Sukardi, Metodologi Penelitian Kompetensi dan Prakteknya, 2003). Metode analisis data menggunakan teknik kualitatif deskriptif bertujuan menggambarkan secara sistematis mengenai apa yang terjadi di lapangan kemudian melakukan analisis dari hasil temuan tersebut dengan menyesuaikan antara temuan dan teori. Analisis data adalah mengelompokkan membuat satu urutan, serta menyingkirkan data sehingga mudah untuk dibaca. Urutan pertama adalah membagi data atas kelompok atau kategorikategori, seperti sesuai dengan masalah dan tujuan, harus lengkap, dan dapat dipisahkan sehingga dapat memecahkan masalah (Moh. Nazir, 2005).

\section{HASIL DAN PEMBAHASAN}

\section{Literasi}

Menurut Baran literasi (literacy) adalah kemampuan secara efektif dan efesien memahami dan menggunakan simbol tulisan. Literasi beasal dari kata yunani yaitu litera (huruf) yang artinya melibatkan sistem-sitem tulisan dan konvensi-konvensi yang menyertainya (Safitra, Juli 2018). mendefinisikan istilah literasi sebagai penggunaan praktik sosial, historis, dan budaya yang berpusat pada penciptaan dan interpretasi makna melalui teks (Ertinawati, 2019). Sedangkan Menurut Kennedy, Dunpy dan Dwyer bahwa literasi mencakup kemampuan untuk membaca, memahami dan menghargai secara kritis berbagai bentuk komunikasi termasuk bahasa lisan, teks tercetak, media penyiaran dan media digital (Rachamatin, 2019). Literasi secara umum diartikan sebagai sebuah kemampuan membaca dan menulis. Sebagaimana dinyatakan dalam kamus Oxford yaitu Literacy is ability to read and write yang Artinya, literasi adalah kemampuan membaca dan menulis (Drs. Tri Septiyantono, 2017).

Dalam Kamus Besar Bahasa Indonesia literasi juga diartikan sebagai sesuatu yang berhubungan dengan tulis-menulis, dalam konteks kekinian, literasi atau literer memiliki definisi dan makna yang sangat luas. Literasi bisa berarti melek teknologi, politik, berpikiran kritis dan peka terhadap lingkungan sekitar. Secara sederhana, budaya literasi dapat didefinisikan sebagai kemampuan menulis dan membaca 
masyarakat dalam suatu Negara. Literasi merupakan sarana untuk mengenal, memahami, dan menerapkan ilmu yang didapat, baik di bangku sekolah, rumah maupun lingkungan sekitar. Secara umum literasi dimaknai sebagai aktivitas membaca dan menulis. Namun, dalam Deklarasi Praha tahun 2003 disebutkan juga literasi mencakup bagaimana seseorang berkomunikasi dalam masyarakat, di zaman yang seperti saat ini kemampuan literasi lebih dari sekadar membaca dan menulis, namun mencakup keterampilan berpikir dalam menggunakan sumber-sumber pengetahuan dalam bentuk cetak, visual, auditori, dan digital (Nurchaili, 2016).

\section{Zakat}

Zakat secara etimologi merupakan bentuk masdar dari kata yang bermakna annama' (tumbuh), al- barakah (barokah), at-thaharah (bersih), as-salah (kebaikan), safwatu asy yäi (jernihnya sesuatu), dan al madu (pujian). Zakat juga bermakna tazkiyah (mensucikan) (Asrifin An Nakhrawi, 2011). Sri Nurhayati dan Wasilah berpendapat bahwa zakat berasal dari bentuk kata "zaka" yang berarti suci, baik, berkah, tumbuh, dan berkembang, Sedangakan menurut az- Zuhaili zakat mempunyai arti annumuw wa az-ziyadah yaitu berkembang, bertambah, berkah, tumbuh, bersih, dan baik, dalam mu'jam al-Wasith dijelaskan bahwa zakat secara bahasa adalah berkah, suci, tumbuh dan bersihnya segala sesuatu (Atabik, 2016). Defisi-definisi tersebut mirip dan saling melengkapi satu sama lain. Sedangkan secara terminologi zakat adalah aktivitas memberikan harta tertentu untuk diserahkan kepada orang-orang yang berhak (Fanani, 2014). zakat berarti bagian dari harta dengan persyaratan tertentu yang diwajibkan Allah SWT. untuk diberikan kepada yang berhak menerimanya sesuai dengan ketentuan yang ada pada Al-Qur'an (Kemenag, 2013).

\section{Kelapa sawit}

Tanaman kelapa sawit (Elaeis guineensis Jacq) merupakan tumbuhan tropis golongan plasma yang termasuk tanaman tahunan. Tanaman Kelapa sawit berasal dari Negara Afrika Barat. Tanaman ini dapat tumbuh subur di Indonesia, Malaysia, Thailand, Dan Papua Nugini. Produk minyak kelapa sawit sebagai bahan makanan mempunyai dua aspek kualitas. Aspek pertama berhubungan dengan kadar dan kualitas asam lemak, kelembaban dan kadar kotoran. Aspek kedua berhubungan dengan rasa, aroma dan kejernihan serta kemurnian produk (Masykur, 2013). 
Analisis pengetahuan dan pemahaman para petani kelapa sawit di kabupaten Labuhanbatu Selatan dilakukan berdasarkan kuesioner yang diberikan kepada para petani kelapa sawit di Kabupaten Labuhanbatu Selatan. Berdasarkan data yang telah dikumpulkan dapat diperoleh hasil penelitian dari literasi zakat para petani sawit tentang zakat di Kabupaten Labuhanbatu Selatan, yaitu terdapat 88 persen informan yang kurang mengetahui literasi zakat di Kabupatan Labuhanbatu Selatan dan terdapat 6 informan dengan presentase 12 persen informan yang mengetahui literasi zakat di Kabuapaten Labuhanbatu Selatan dengan sangat baik. Bila dilihat dari penjelasan tersebut, hampir semua informan memiliki pengetahuan dasar tentang literasi zakat. Namun, tidak semua informan memahami betul jenis-jenis zakat. Hal ini di buktikan dengan masih banyaknya informan yang kurang dalam mengetahui zakat fitrah dan zakat harta. Hal ini dapat dilihat dari banyaknya informan yang masih belum mengetahui perbedaan kadar zakat harta dan zakat fitrah. Informan hanya mengetahui zakat harta hanya diberikan kepada orang yang berhak menerima. Meskipun informan mengetahui zakat tetapi tidak menerapkannya sebagai tanggung jawabnya sebagai seorang muslim. Bahkan informan justru lebih memilih untuk menunaikan haji daripada harus membayarkan zakatnya sedangkan, zakat sendiri merupakan rukun Islam yang ke 4 sebelum naik haji yang seharusnya lebih baik ditunaikan lebih dahulu sebelum berhaji. Maka, hanya akan menjadi manusia yang merugi sebab tidak memberikan hak orang lain pada harta yang dimiliki. Dalam hal ini dibutuhkan kesadaran masyarakat sebagai seorang muslim dalam membayarkan zakat hartanya (Petani Kelapa Sawit, Wawancara, 25 September, 2021).

Kepala BASNAZ Kab. Labuhanbatu Selatan menyatakan dalam wawancaranya bahwa pemahaman masyarakat mengenai dasar zakat bagus, yaitu pemahaman masyarakat mengenai zakat fitrah yang dikeluarkan pada tiap bulan Ramadhan, sedangkan mengenai zakat harta sendiri di Kabupaten Labuhanbatu Selatan masih sangat kurang dan jauh dari kata cukup, masih banyak masyarakat yang tidak mengetahui bahwasanya harta yang mereka miliki merupakan titipan dari Allah SWT dan juga merupakan harta umat yang sebenarnya waib untuk dikeluarkan apabila telah mencapai haulnya dan cukup kadarnya dan sampai saat ini budaya nepotisme masih berlaku di masyarakat kita, hal ini termasuk kelemahan yang terjadi di masyarakat Kabupaten Labuhanbatu Selatan, hal tersebut sudah menjadi budaya yang mendarah daging dan cukup sulit untuk diubah yang mana mereka masih lebih memprioritaskan keluarga mereka sendiri untuk mendapat dana zakat tersebut. Namun, kami dari pihak BAZNAS selalu mengupayakan agar pembagiannya sama rata dan tepat sasaran dan 
selalu menghimbau kepada tiap-tiap kepengurusan UPZ di tiap-tiap desa agar memberikannya sama rata kepada setiap mustahik yang ada di seluruh Kabupaten Labuhanbatu Selatan (H. Khaldunsyah. Torgamba, wawancara ,16 September 2021).

\section{KESIMPULAN}

Berdasarkan pembahasan yang telah dipaparkan di atas, dapat diambil kesimpulan sebagai berikut: Peneliti menyimpulkan terdapat tiga turunan literasi yang mempengaruhi masyarakat, yakni pengetahuan masyarakat tentang zakat, kemampuan zakat, dan Kemampuan seseorang dalam mengelolaan informasi dan pengetahuan tentang zakat. Selain itu faktor yang mempengaruhi literasi zakat adalah kepercayaan masyarakat terhadap Lembaga amil zakat. Dari 50 informan ada 87\% yang kurang mengetahui pengetahuan dan pemahaman mengenai kewajiban zakat lanjutan di Kabupaten Labuhanbatu Selatan. Selain itu, 13\% informan memiliki pengetahuan dan pemahaman tentang zakat. Hal ini di butuhkan yang namanya kesadaran dalam melakukan kewajibannya sebagai umat muslim untuk berzakat sebagaimana dalam rukun Islam yang ke 4 kewajiban dalam berzakat, baik itu zakat fitrah atau pun zakat harta. Bukan hanya tentang literasi zakat tetapi juga kepercayaan masyarakat terhadap Lembaga Amil Zakat, sebab kepercayaan adalah faktor yang mempengaruhi masyarakat dalam membayar zakat di badan Lembaga Amil Zakat atau Baznas di Kabupaten Labuhanbatu Selatan. 


\section{DAFTAR PUSTAKA}

(BPS), B. p. (2020). Badan pusat Statistik (BPS), "Produksi Tanaman Perkebunan PTPPN II, III, Dan IV Menurut Jenis Tanaman(Ton), 2015-2018.

Agustin. (2018, 8 1). Analisis Faktor Yang Memengaruhi Petani Kelapa Sawit Dalam Membayar Zakat Hasil Perkebunan Di Kabupaten Labuhanbatu Selatan . IPB , p. 3.

Antariksa. (2015). Preferensi Muzakki Dalam Menyalurkan Zakat. Jurnal Antimicrobial Agant and Chemotherapy 58. Vol. 1 No. $12,57$.

ash-Shiddieqy, P. D. (2009). Pedoman Zakat. Yogyakarta: Pustaka Riski putra.

Asrifin An Nakhrawi. (2011). In Sucikan Hati Dan Mari Bertambah Kaya Bersama Zakat (p. 11). Jakarta: Delta Prima Press.

Atabik, A. (2016). Peran Zakat Dalam Pengentasan Kemiskinan. Jurnal Zakat dan Wakaf, Vol. 2 No.2 , 340.

bandur, A. (2016). Penelitian Kualitatif Metodologi, Desain, dan Teknik Analisis Data dengan NVIVO 11 Plus. Jakarta: Mitra Wacana Media.

Corbin, S. \&. (2003). Dasar-Dasar Penelitian Kualitatif. Yogyakarta: Pustaka pelajar.

Drs. Tri Septiyantono, M. (2017). Konsep Dasar Literasi Informasi. Konsep Dasar Literasi Informasi , 5 .

Ertinawati, I. L. (2019). Literat Melalui Presentasi. Jurnal Metaedukasi. Vol. 1 No.1 , 3.

Ezhar, M. A. (2019). Literasi Zakat Masyarakat: Tinjauan Tingkat Pendidikan Dan Religiusitas (Studi Pada Desa Cengkong Kabupaten Karawang). Bandung : Universitas Pendidikan Indonesia , 1-2.

Fanani, B. ( 2014). Penghimpunan Dana Zakat Nasional (Potensi, Realisasi, Dan Peran Penting Organisasi Pengelolaan Zakat ). Permana Jurnal perpajakan dan akutansi. Vol. 5 No.2, 7 .

H. Khaldunsyah. Torgamba, wawancara ,16 September 2021.

Kemenag. (2013). Metode Praktis Penetapan Nisab Zakat Model Dinamis Berdasarkan Standar Nilai Emas Dan Kebutuhan Hidup Layak (KHL) Provinsi. Jakarta: Metode http://jurnal.iain-padangsidimpuan.ac.id/index.php/JISFIM 
Praktis Penetapan Nisab Zakat Model Dinamis Berdasarkan Standar Nilai Emas Dan Kebutuhan Hidup LayakKementrian agama Republik indonesia.

Marinda. (2016). Analisis Strategi Menghimpun Dana Zakat, Infak, Dan Sedekah Pada Rumah Zakat Cabang Palembang. Palembang: UIN Raden Fatah Palembang , 2.

Masykur. (2013). Pengembangan Industri Kelapa Sawit Sebagai Penghasil Energi Bahan Bakar Alternatif Dan Mengurangi Pemanasan Global (Studi Di Riau Sebagai Penghasil Kelapa Sawit Terbesar Di Indonesia). Jurnal Revormasi. Vol. 3 No.2 , 99.

Moh. Nazir, M. D. (2005). Metode Penelitian. Daraussalam: Ghalia Indonesia.

Moleong, L. J. (2012). Metode Penelitian Kualitatif. Bandung: Remaja Rosdakarya.

Noor, J. (2013). Metodologi Penelitian. Jakarta: Kencana.

Nur. (2018). Strategi Fundrising Zakat: Literasi Zakat Produktif Dan Zakat Profesi ( Studi Pada BMT Muda Jatim Mitra Inisiatif Zakat Indonesia ). Strategi Fundrising Zakat Proceedings of Annual Conference on Community Engagement. Vol. 2 No.1 , 560.

Nurchaili. (2016). Menumbuhkan Budaya Literasi Melalui Buku Digital. Libria Vol. 8 No.2, 201.

(25 September, 2021). Petani Kelapa Sawit, Wawancara. Labuhanbatu Selatan.

Rachamatin, D. (2019). Literasi digital abad 21 bagi mahasiswa PGSD: apa, mengapa, dan bagaimana. Current Research in Education: Conference Series Journal , 2.

Rachmat, K. d. (2010). Teknik Praktis: Riset Komunikasi. jakarta: kencana .

Rouf, M. A. (2011). Analisis Faktor-Faktor Yang Mempengaruhi Minat Masyarakat Membayar Zakat Di Rumah Zakat Cabang Semarang. Semarang:Institut Agama Islam Negri Walisongo , 10-52.

Safitra, A. (Juli 2018). Efektivitas Literasi Media Dalam Meningkatkan Minat Baca Melalui Kelompok Gerakan Langkat Pintar. Jurnal Interaksi, Vol 2 No. 2 , 183.

Sukardi. ( 2003). Metodologi Penelitian Kompetensi dan Prakteknya. Jakarta: PT. Bumi Aksara. http://jurnal.iain-padangsidimpuan.ac.id/index.php/JISFIM 
Sukardi. (2003). Metodologi Penelitian Kompetensi dan Prakteknya. Jakarta: PT. Bumi Aksara.

Vijaya, K. A. (2014). Metodologi penelitian bisnis. Yogyakarta: Graha Ilmu.

Vijaya, K. A. (2014). Metodologi penelitian bisnis. Yogyakarta: Graha Ilmu.

Zuhriah, N. (2006). Metodologi Penelitian Sosial dan Pendidikan. Jakarta: Bumi Aksara. 